\title{
PATRIMÔNIO DE AFETAÇÃO - SEgURANÇA NA AQUISIÇÃO DE IMÓVEIS INCORPORADOS
}

\author{
SEgREgATED PORTFOLIO ASSETS - THE LEGAL CERTAINTY IN THE REAL ESTATE \\ ACQUISITION
}

\author{
Carlos Eduardo Eyng ${ }^{1}$ \\ Fabiano Hartmann Peixoto ${ }^{2}$
}

\section{Resumo}

O presente estudo parte da relevância da aquisição imobiliária e da especial contribuição para isso dada pela incorporação imobiliária. O trabalho tem como objetivo investigar o instituto do Patrimônio de Afetação nas Incorporações Imobiliárias e analisar a segurança jurídica que ele poderia conferir. Delimitou-se o conceito de condomínio edilício e de incorporação e, após, os elementos componentes e o conceito de patrimônio de afetação. O interesse pela temática ocorreu também devido ao impacto do problema ainda vivenciado por uma considerável parcela da população brasileira em decorrência do longo processo falimentar da incorporadora ENCOL. Analisaram-se (método dedutivo) também as alterações legislativas provenientes de tal episódio, bem como as possíveis críticas e desafios nesse processo de aquisição imobiliária, inclusive pelo entendimento jurisprudencial atual.

Palavras-chave: Propriedade em condomínio, Incorporação, Patrimônio de Afetação

\begin{abstract}
The present study arises from the relevance of the real estate acquisition and from the special contribution to that given by the real estate development. The paper aims to investigate the institute of Segregated Portfolio Assets in Real Estate Development, and analyse the legal certainty that the former could attribute to the latter. The concepts of condominium ownership and of real estate development were delimited, and afterwards, their constituent elements and the concept of Segregated Portfolio Assets. The interest in the theme also occurred due to the impact of the problem still experienced by a considerable portion of the Brazilian population as a result of the bankruptcy of ENCOL developer. The legislative changes arisen from such an episode were analysed (deductive method), as well as the possible criticisms of this process of acquiring real estate and its challenges, including the current understanding of jurisprudence.
\end{abstract}

Keywords: condominium ownership, real estate development, Segregated Portfolio Assets

\footnotetext{
${ }^{1}$ Graduado em Direito CESUSC. E-mail: ceeyng@terra.com.br

2 Professor Adjunto de Direito Privado e Relações Econômicas da Faculdade de Direito da Universidade de Brasília-UnB. E-mail: fabiano_hp@hotmail.com
} 


\section{INTRODUÇÃO}

A segurança ao adquirir a propriedade de um imóvel é fundamental para a sociedade brasileira. A utilização de economias de "uma vida" na aquisição da "casa própria" confere enorme importância ao assunto que será debatido.

Apropriando-se do raciocínio exato de Antonio Hernandez Gil (1987), em sua obra La posesion como instituição jurídica e social, onde se demonstra a importância existencial da posse (em sentido amplo) e o papel tranquilizador gerado por um espaço físico próprio, isto é, a propriedade vista como espaço vital. Pode-se continuar estudando que a aquisição imobiliária, mesmo atualmente com a multiplicidade de valores e interesses de uma sociedade plural, continua sendo um fator que move prioritariamente as condutas humanas.

Após o desfecho do famoso caso ENCOL, em que inúmeros brasileiros perderam a oportunidade de realizar o sonho da casa própria após a falência da incorporadora, os negócios jurídicos de promessas de compra sofreram mudanças.

Para tanto, será realizada a abordagem de pesquisa bibliográfica juntamente com julgados relacionados ao assunto. Desta forma, vindo a compreender a forma de visão da situação exercida pelo Poder Judiciário, assim como pelo Poder Legislativo, através do Congresso Nacional, na alteração da legislação de incorporações imobiliárias. Com uma descrição dos principais impactos sobre as garantias ao promitente comprador, assim como uma breve visão dos reflexos aos agentes financeiros que capitalizam as incorporadoras por todo território nacional.

\section{PANORAMA BRASILEIRO}

As aquisições imobiliárias, para grande parte da população, são objetivos de vida. Dessa forma, é fundamental a segurança destes negócios jurídicos e, portanto, a estabilidade do incorporador, para evitar surpresas desagradáveis ao adquirente.

Tal situação foi vivenciada por milhares de brasileiros no caso ENCOL. A falência da incorporadora acarretou inúmeros prejuízos de ordem social, econômica e financeira. Esse episódio causou grande comoção social, e também por conta disso o Congresso Nacional elaborou a Lei Federal no 10.931/04, a partir da Medida Provisória no 2221/01.

O episódio da ENCOL não seria um caso isolado; outras incorporadoras encontravam-se nas mesmas situações. A primeira solução encontrada foi vinculada aos Tribunais, os quais vinham lidando com relações individuais e posteriormente a regulamentação da atividade. Porém, a via 
judicial não acompanhava o desejo individual e, muitas vezes, não era efetiva; era comum que o indivíduo empregasse no imóvel a "poupança de uma vida" e, apesar de condenado o incorporador, não conseguia receber de volta a quantia paga.

A insegurança era muito grande, pois os possíveis adquirentes não possuíam garantias de que o episódio ENCOL não se repetiria com eles. Por isso, houve uma significativa queda na aquisição de imóveis na planta (FERNANDES, ARBEX, 1997). Vinculado a essa questão, estava a improcedência da adjudicação dos bens hipotecados da incorporadora pelos agentes financeiros. Os Tribunais decidiam no sentido e manter as unidades autônomas ao adquirentes, frustrando a garantia real do agente financeiro.

Para ilustrar a situação, somente no caso ENCOL, as dívidas da empresa atualmente estão perto de um bilhão de reais, mas a liquidação de seu patrimônio rendeu até agora pouco mais de trezentos milhões. (RELATÓRIO, 2013)

Com a multiplicação do descumprimento das obrigações assumidas pelas incorporadoras provocou uma desestabilização, pois como menciona Sílvio de Salvo Venosa (2013) "uma obrigação descumprida ou mal cumprida, ou cumprida com atraso, desempenha uma papel de uma célula doente no organismo social; célula essa que pode contaminar vários órgãos do organismo.

Nesse contexto, o conteúdo deste trabalho visa apontar um possível incremento na segurança jurídica proporcionado pelo instituto do patrimônio de afetação, iniciando por conceitos anteriores, como a noção de condomínio.

\section{PROPRIEDADE HORIZONTAL E CONDOMÍNIO EDILÍCIO}

De uma maneira geral a mesma coisa não pode estar sob o domínio de mais de uma pessoa, contudo sem perder de vista que a propriedade é um direito, esse pode pertencer a vários indivíduos ao mesmo tempo (FARIAS; ROSENVALD, 2015).

O condomínio comum pro indiviso ${ }^{3}$ é aquele em que a coisa pertence simultaneamente a duas ou mais pessoas, que têm direito sobre ela na sua totalidade, e não sobre partes localizadas, ainda que perfeitamente quantificadas. Os coproprietários podem usar e fruir de todo o bem e

\footnotetext{
${ }^{3}$ Alguns autores estabelecem uma distinção quanto ao aspecto subjetivo e objetivo do condomínio: quanto ao aspecto subjetivo há uma comunhão de um direito pertencente a mais de uma pessoa; quanto ao aspecto objetivo, há uma indivisão, isto é, a coisa encontra-se em um estado sob a incidência de vários direitos concorrentes. O status pro indiviso seria encontrado na comunhão que perdura de fato e de direito e o status pro diviso só haveria de direito. Farias e Rosenvald (2015) desenvolvem esse tema.
} 
exercem seus direitos na proporção da cota que possuem, mas sem excluir igual direito dos demais condôminos (GONÇALVES, 2012) ${ }^{4}$.

As necessidades decorrentes da grande concentração urbana, porém, exigiram a criação de outras formas de utilização do espaço ${ }^{5}$ (CHALHUB, 2003, p. 125).

Surgiu assim a denominada propriedade em planos horizontais, que combina a propriedade individual e a copropriedade, ligadas entre si por um nexo de funcionalidade (CHALHUB, 2003, p. 129).

Para Mario Mezzari (2010, p. 29), propriedade horizontal e condomínio edilício são conceitos que não se confundem. A propriedade horizontal é a situação jurídica da propriedade, compartimentada em planos horizontais e individuada, dentro destes compartimentos, em unidades autônomas de propriedade privada e em áreas destinadas ao uso coletivo. Nem sempre ela resulta de um condomínio, pois o proprietário único de um edifício pode decidir submetê-lo ao sistema da propriedade horizontal, gerando assim diversas unidades passíveis de alienação ou oneração isolada. Já o condomínio edilício concerne às relações entre os diferentes proprietários dessas unidades autônomas e suas relações condominiais sobre as coisas de uso comum e o terreno. Para Farias (2015, p. 601) o condomínio edilício reúne duas figuras, ou seja, é um direito real que combina a propriedade individual (sobre as chamadas unidades autônomas) e a copropriedade (sobre partes comuns).

A propriedade horizontal tem por objeto as edificações ou conjuntos de edificações constituídos por (i) partes que são objeto de propriedade privativa, as unidades autônomas, isoladas das demais e das partes de uso comum, e por (ii) partes que são objeto de propriedade comum, que incluem a estrutura sobre que se assentam as unidades e as demais partes que

\footnotetext{
${ }^{4}$ Ebook, devido à falta de paginação deste material, a referência do mesmo será utilizada apenas AUTOR, Ano.

${ }^{5}$ Uma nota trazida por Farias; Rosenvald (2015, p. 600) , referindo a Caio Mario Pereira ao elaborar projeto de lei para regular o assunto no Brasil, representa bem esse cenário: "O fenômeno social da sobreposição de unidades residenciais, relativamente recente na história mundial, é aferido pelo doutrinador: 'Por toda parte, na verdade, e dentro de um período relativamente curto, a ponto de autorizar a afirmativa de uma ação simultânea, o legislador de vários países repensou a noção da divisão da coisa imóvel e cuidou de regulamentá-la. Em Portugal, o Decreto-Lei n. 40.333, de 14 de outubro de 1955, regulou minuciosamente o condomínio de edifícios. Na Bélgica, a Lei de 1924 modificou o Código Civil, no que diz respeito a copropriedade. Na França a Lei de 28 de junho de 1938 instituiu novo regime para a propriedade comum. Na Itália, legislação de 1934 disciplinou em termos modernos as relações entre condôminos. Na Espanha, Lei de 1939 ofereceu nova regulamentação à comunhão de bens. Na Argentina, a Lei de 1948 detidamente tratou da propriedade horizontal. O Chile o fez em 1937, o Uruguai em 1946, a Venezuela em 1957'”.
} 
permitem a utilização dessas unidades, a ligação entre si e o acesso ao logradouro público (CHALHUB, 2003, p. 125).

A propriedade individual ou privativa tem por objeto as unidades imobiliárias autônomas (apartamentos, salas, lojas, vagas de garagem, etc), que embora material e juridicamente vinculadas às partes comuns, são dotadas de autonomia material e jurídica, objeto de propriedade exclusiva, e suscetíveis de livre e exclusivo uso, fruição, ocupação e disposição pelos respectivos titulares (GONÇALVES, 2012).

A copropriedade ou propriedade comum tem por objeto o terreno, a estrutura do edifício (saguão, elevadores, corredores, portaria, etc), a rede geral de distribuição de água e esgoto, as áreas de circulação e de acesso ao logradouro e tudo o mais que tiver destinação comum a todos que ocupem as unidades autônomas. Essa propriedade deve ser exercida em comum pelos condôminos, que podem usá-la e fruir dela de modo compatível com sua função e destinação e sem excluir igual direito dos demais condôminos. Ela é insuscetível de desmembramento ou de alienação separadamente da unidade imobiliária de que seja titular o condômino; sobre ela, cada condômino é titular de uma fração ideal (CHALHUB, 2003, p. 126-128).

Importante observar que o regime da propriedade horizontal independe da pluralidade de partícipes, pois pode ser instituído pelo proprietário singular (MEZZARI, 2010, p. 29). Já o condomínio especial pressupõe pluralidade subjetiva dos proprietários das unidades isoladas. Não haverá condomínio especial num edifício composto por várias unidades, todas pertencentes a um só proprietário (CHALHUB, 2003, p. 130).

Na propriedade horizontal, a unidade imobiliária vincula-se ao conjunto de que faz parte, e todo esse conjunto, formado por partes comuns e partes privativas, é um bem incindível (CHALHUB, 2003, p. 128). A estrutura jurídica, a própria disposição das unidades autônomas e a situação das partes de uso comum, estas indispensáveis à utilização de todas as unidades, tornam compulsório o estado de indivisão e contemplam situações típicas do direito de vizinhança (CHALHUB, 2003, p. 129).

A propriedade horizontal pode ser instituída sobre uma ou mais edificações, independentemente do número de pavimento e do uso a que se destina a unidade. É cabível para vários tipos de edificações, desde um prédio simples de um único pavimento, um sobrado, um edifício de vários andares, um conjunto de edifícios, um conjunto de casas térreas ou assobradadas construídas em terreno comum, e até mesmo a formas mistas (MEZZARI, 2010, p. 28-35). 
A cada unidade autônoma deve corresponder, como parte inseparável, uma fração ideal relativamente ao terreno e partes comuns (art. 1332, inciso II, do Código Civil). É com base na fração ideal que se estabelecem vários direitos e deveres, como a cota de participação nas despesas do condomínio, a contagem dos votos em assembleias gerais, a cota de propriedade no terreno remanescente em caso de desapropriação parcial, etc (MEZZARI, 2010, p. 45).

Um condomínio especial de unidades autônomas pode ser estabelecido mediante ato entre vivos ou por testamento, por instrumento público ou particular, e só se constitui com o registro do instrumento constitutivo no Registro de Imóveis do local do imóvel. Em qualquer caso, o instrumento de instituição deve conter os elementos essenciais de caracterização da propriedade especial: a discriminação e individualização das unidades autônomas e das partes comuns; a determinação da fração ideal atribuída a cada unidade, relativamente ao terreno e partes comuns; e a destinação das unidades autônomas (CHALHUB, 2003, p. 130-132).

A instituição mediante testamento ocorre quando nele o proprietário de edifício composto por unidades autônomas dispõe sobre a instituição de condomínio especial, descrevendo e caracterizando cada unidade, atribuindo-Ihes autonomia, discriminando as partes de uso comum, estabelecendo as regras de uso e administração, etc (CHALHUB, 2003, p. 130).

A instituição também pode ocorrer por ato unilateral do proprietário; no caso de um edifício já construído, o proprietário, para alienar suas unidades autônomas, deve previamente realizar a instituição, especificação, discriminação e convenção de condomínio (MEZZARI, 2010, p. 68).

A instituição pode ainda ocorrer por acordo de vontades, quando um grupo de pessoas, titulares de direitos sobre partes ideais de um terreno ou empreendimento, com relações regidas pelo condomínio comum, resolvem unanimemente instituir o regime especial da propriedade horizontal contido no estatuto do condomínio edilício (MEZZARI, 2010, p. 69).

Mas a hipótese mais frequente na prática é a instituição por iniciativa de um incorporador imobiliário (CHALHUB, 2003, p. 130).

\section{INCORPORAÇÃO IMOBILIÁRIA E PATRIMÔNIO DE AFETAÇÃO}

A incorporação imobiliária é "a atividade exercida com o intuito de promover e realizar a construção, para alienação total ou parcial, de edificações ou conjunto de edificações compostas de unidades autônomas" (artigo 28, parágrafo único, da Lei n. 4.591, de 16 de dezembro de 1964). 
A disciplina específica da incorporação imobiliária e do condomínio edilício foi instituída pela Lei n. 4.591/64, mas o Código Civil vigente revogou, dessa lei, os dispositivos pertinentes ao condomínio edilício. Permaneceram vigentes os dispositivos relativos à incorporação imobiliária.

A incorporação é apenas o período pré-comunal em que se praticam os atos para estabelecimento da comunhão pro diviso em unidades autônomas. Ela se caracteriza pela finalidade do negócio jurídico: promover a construção de edificação ou conjunto de edificações para alienação, antes do período de construção ou durante ele, das unidades autônomas que as integrarão (SILVA, 2010, p. 23).

Vale destacar que a venda, a proposta de venda e o compromisso de compra e venda das frações ideais a que se vinculam unidades autônomas devem necessariamente ser celebrados antes da construção ou durante ela. Por isso, não caracteriza incorporação imobiliária a alienação das frações ideais e respectivas unidades autônomas quando a edificação já está pronta (SILVA, 2010, p. 28).

Da mesma forma, não caracteriza incorporação imobiliária a venda de frações ideais do terreno, sem vinculação a unidade autônoma, em edifício a ser construído; o condomínio que se forma em decorrência dessa venda é o condomínio voluntário regido pelos arts. 1314 e seguintes do Código Civil (SILVA, 2010, p. 47).

A incorporação imobiliária, portanto, é um contrato único, tipificado em lei, que conjuga aspectos de constituição de direito real e aspectos reais, ou seja, prestações típicas de outros contratos distintos (SILVA, 2010, p. 41).

Os aspectos de constituição de direito real estão no registro da incorporação no Registro de Imóveis, nos registros de contratos de alienação das frações ideais a que se vinculam as unidades autônomas futuras e no registro da instituição do condomínio edilício (SILVA, 2010, p. 46).

Os aspectos negociais ou obrigacionais estão nas diferentes obrigações de dar e fazer assumidas pelas partes, como, por exemplo, a construção do edifício, a obrigação do incorporador de celebrar o contrato de incorporação no prazo do art. 35 da Lei n. 4.591/64, a obrigação do adquirente de pagar o preço, etc. (SILVA, 2010, p. 47).

O contrato de incorporação imobiliária é bilateral ou sinalagmático, porque produz direitos e obrigações tanto para o incorporador como para o adquirente. Por isso, nele é possível invocar a exceptio non adimpleti contractus (art. 476 do Código Civil). É, também, contrato do tipo oneroso comutativo, pois ambos os contratantes suportam sacrifício patrimonial para obter vantagem, e 
ambos podem antever de imediato os benefícios patrimoniais que receberão em troca das respectivas prestações (SILVA, 2010, p. 48).

O contrato de incorporação imobiliária é formal, porque deve ser celebrado por escrito, mas não necessariamente exige instrumento público. Só se exigirá escritura pública quando através do próprio contrato o incorporador vender a fração ideal de terreno a que vinculada futura unidade autônoma, a der em permuta, em novação, em dação em pagamento, e o valor do imóvel superar trinta salários mínimos (artigo 108 do Código Civil) (SILVA, 2010, p. 50).

Aqui já se identifica uma possível fonte de crise para os contratos de incorporação. Eles têm natureza instrumental para a aquisição da propriedade. São contratos, mas tem destino na aquisição de um direito real. Há aqui uma linha tênue que diferencia a transitoriedade típica e inegável das obrigações e dos contratos para a perenidade da relação real típica de propriedade via incorporação imobiliária.

Pode-se dizer que a incorporação imobiliária se compõe de elementos formais, objetivos e subjetivos. Os elementos subjetivos são o incorporador e os adquirentes dessas unidades autônomas. O elemento objetivo corresponde às frações ideais de terreno vinculadas a futuras unidades autônomas em edifícios a serem construídos, ou em construção. Os elementos formais englobam desde o registro da incorporação no Registro de Imóveis até a averbação da construção e o registro da instituição do condomínio edilício (SILVA, 2010, p. 29-30).

\section{Elementos subjetivos}

O incorporador imobiliário é a pessoa física ou jurídica que, independentemente de promover ou não a construção, vende ou promete vender frações ideais de terreno objetivando a vinculação delas a futuras unidades autônomas, em edificações ou conjunto de edificações a construir ou já em construção, ou que meramente aceita proposta para efetivar tais transações, levando a termo a incorporação e se responsabilizando pela entrega, a certo prazo e condições, da obra concluída (artigo 29 da Lei n. 4.591/64).

Só pode ser incorporador o proprietário ou titular de direitos à aquisição do imóvel (promitente comprador, promitente permutante ou cessionário destes), o construtor ou o corretor de imóveis (MEZZARI, 2010, p. 88).

O incorporador ainda, pessoalmente ou mediante terceiro em seu nome, solicita e obtém dos órgãos públicos as aprovações e licenças necessárias; negocia com instituição financeira a obtenção de financiamento para cobrir os custos do empreendimento; averigua os preços de 
serviços de terceiros para a construção. Dentro dessa atividade ampla, identifica-se o núcleo da atividade incorporativa: o negócio jurídico denominado contrato de incorporação imobiliária, pelo qual o incorporador se obriga a promover a construção de edifício e a, antes da construção ou durante ela, alienar as frações ideais a que se vinculam as futuras unidades autônomas em que ele será dividido, mediante pagamento do preço ajustado (SILVA, 2010, p. 26).

O incorporador, em síntese, orienta e coordena a união de diversas outras pessoas com interesses distintos, que celebram negócios jurídicos interligados entre si e destinados à consecução do objetivo de concluir a construção, instituir o condomínio edilício e após, transferir aos adquirentes a propriedade das unidades autônomas (SILVA, 2010, p. 25 e 40).

$\mathrm{O}$ adquirente celebra com o incorporador um contrato de promessa de compra e venda, que pode ser registrado na matrícula do imóvel (art. 32, §2o, da Lei n. 4.591/64) (SILVA, 2009, p. 246).

A incorporação imobiliária serve para proteger o adquirente, porque no momento da alienação, as unidades autônomas ainda não são imóveis com existência jurídica autônoma e nem com existência física completa (SILVA, 2010, p. 29).

\section{Elemento objetivo}

A construção pode ser promovida pelo incorporador, por terceiro por ele contratado ou por construtor contratado diretamente pelos adquirentes (art. 48 da Lei n. 4.591/64).

A alienação da fração ideal do terreno feita através do contrato de incorporação pode se dar mediante compra e venda, compromisso de compra e venda, permuta, dação em pagamento, novação. Em cada um desses casos, os elementos do tipo do contrato correspondente à causa da alienação integrarão o contrato de incorporação imobiliária (SILVA, 2010, p. 42-43).

Mas como adverte José Marcelo Tossi Silva (2010, p. 58), seja qual for a modalidade de negócio jurídico empregada na alienação, o contrato de alienação de fração ideal a que se vincula futura unidade autônoma sempre deverá:

1. Identificar as partes com os dados necessários ao registro;

2. Mencionar, caso o incorporador não seja o proprietário do terreno, quem é o proprietário e a que título o incorporador promove a incorporação;

3. Identificar o imóvel alienado, caracterizando o terreno, informando o número do registro da incorporação (art. 32, §3으, da Lei n. 4.591/64), e especificar a futura unidade autônoma 
e as frações que the correspondem no terreno e nas coisas comuns (art. 32, alíneas "e" e "i", da Lei n. 4.591/64);

4. Conter o projeto e o memorial descritivo das edificações apresentados no registro da incorporação (art. 48, §1ํㅡ, da Lei n. 4.591/64);

5. Identificar o regime adotado na incorporação (art. 35 da Lei n. 4.591/64) e, se for ocaso, conter as cláusulas da contratação da construção ou identificar como ela será contratada (art. 48 da Lei n. 4.591/64);

6. Identificar os ônus reais que gravarem o imóvel, assim como eventuais ações contra os alienantes que possam ter como garantia o imóvel em questão (art. 37 da Lei n. 4.591/64);

7. Caso existam ocupantes no imóvel, são necessárias as condições para desocupação do mesmo (art. 38 da Lei n. 4.591/64);

\section{Elementos formais}

O registro da incorporação imobiliária perante o Registro de Imóveis é obrigatório, não podendo o incorporador negociar sobre unidades autônomas, e nem mesmo veicular propaganda, sem ter arquivado no cartório competente os documentos previstos no art. 32 da Lei n. 4.591/64, além de outros como o contrato-padrão (art. 67, §3o, da Lei n. 4.591/64) e a anotação de responsabilidade técnica (Lei n. 6.496/77) (MEZZARI, 2010, p. 91-95).

O registro tem validade de 180 dias. Se durante esse prazo for negociada alguma unidade ou contratado financiamento para a construção, considera-se efetivada a incorporação, e o incorporador poderá negociar as demais futuras unidades. Se, findo o prazo, a incorporação ainda não houver se concretizado, o incorporador só poderá negociar unidades depois de revalidar o registro através da atualização dos documentos exigidos pelo art. 32 da Lei n. 4.591/64 (art. 33 da Lei n. 4.591/64) (MEZZARI, 2010, p. 143).

O registro da incorporação, porém, não institui o regime da propriedade horizontal. É preciso um registro específico, o da instituição de condomínio, simultaneamente à averbação da conclusão da obra. É que a incorporação é procedimento efêmero, válido enquanto não terminada a obra e criado apenas para garantir aos compradores a entrega de suas unidades. Essas unidades, porém, uma vez concluído o edifício, só passam a ter existência jurídica com o registro da instituição, oportunidade em que basta ao incorporador, além de apresentar o habitasse, declarar que o projeto foi cumprido tal como arquivado no registro e que a individuação das unidades é a mesma constante do registro da incorporação (MEZZARI, 2010, p. 150-160). 
O incorporador não pode registrar a incorporação somente para afetar o imóvel e prevenir-se de eventuais alterações normativas, deixando para efetivamente promover a incorporação e alienar as frações ideais só quando the convier e fora dos prazos legais (SILVA, 2010, p. 27).

\section{O patrimônio de afetação}

Na relação jurídica desenvolvida pela incorporação imobiliária, de um lado o responsável pela viabilização da execução da obra, o incorporador e, de outro, os investidores, compradores, empreiteiros, fornecedores, corretores, há a necessidade de um ambiente jurídico com potencialização da segurança.

O patrimônio de afetação é instrumento jurídico coerente para atribuir às relações contratuais acima exemplificadas, substancialmente valorosas, este ambiente, pois permite individualizar o patrimônio, que em última análise seria responsabilizado em um eventual inadimplemento das obrigações jurídicas estruturadas na execução da obra. Isso auxilia na construção de uma maior harmonia nos elementos estruturais obrigacionais e no desenvolvimento da incorporação imobiliária, conveniente ao incorporador e aos demais envolvidos nos negócios jurídicos decorrentes.

Sobre o marco legislativo, a Medida Provisória n. 2.221, de 4 de setembro de 2001, posteriormente transformada na Lei n. 10.391, de 2 de agosto de 2004, instituiu o patrimônio de afetação nas incorporações imobiliárias. O incorporador pode então requerer ao registrador imobiliário que averbe, na matrícula em que registrada a incorporação, que o terreno e suas acessões ficarão apartados do patrimônio do incorporador (art. 31-A da Lei n. 4.591/64). O imóvel ficará destinado tão-somente à execução do empreendimento, não podendo ser dado em garantia de outras dívidas ou obrigações, e ficará livre de responder por outras dívidas do incorporador ou do proprietário do terreno que não sejam diretamente vinculadas à execução da incorporação (MEZZARI, 2010, p. 138).

É dizer: o regime de afetação "destaca" do patrimônio do incorporador os bens componentes de uma determinada incorporação imobiliária (o terreno, o edifício em construção, os materiais, etc.), que passam a constituir um patrimônio separado não sujeito pelas dívidas gerais do incorporador, mas apenas às dívidas relativas à incorporação em questão. Em caso de falência do incorporador, o patrimônio de afetação não integrará a massa falida global, mas uma massa isolada destinada a saldar os credores dessa incorporação específica (SILVA, 2009, p. 253). 
A instituição do regime de afetação é opção do incorporador (art. 31-A, caput, da Lei n. 4.591/64). Além disso, exige contabilidade e conta bancária apartadas da contabilidade geral e das contas do incorporador, de modo que se possa saber o fluxo de dinheiro, o que está sendo adquirido, etc. (art. 31-D, incisos $V$ e VIII, da Lei n. 4.591/64). A lei, porém, não prevê expressamente sanção para o incorporador que viola essa regra (SILVA, 2009, p. 254).

O requerimento para averbar a afetação pode ser feito a qualquer tempo (art. 31-B da Lei n. 4.591/64), com a anuência do titular do direito aquisitivo, se já alguma unidade já houver sido negociada (MEZZARI, 2010, p. 138). A instituição do regime no curso da incorporação, porém, oferece dificuldades práticas: embora em tese seja possível desmembrar da contabilidade da incorporadora a parte relativa à incorporação específica, já se vê que aumenta a possibilidade de fraude (SILVA, 2009, p. 254).

São deveres do incorporador, entre outros: administrar bem o patrimônio de afetação, inclusive mediante adoção de medidas judiciais necessárias; manter apartados os bens e direitos objeto de cada incorporação; diligenciar a captação dos recursos necessários à incorporação e aplicá-los; entregar à Comissão de Representantes, no mínimo a cada três meses, demonstrativo do estado da obra e de sua correspondência com o prazo pactuado ou com os recursos financeiros que integrem o patrimônio de afetação recebidos no período (art. 31-D da Lei n. 4.591/64).

A instituição de patrimônio de afetação pode ser muito útil para os adquirentes se a Comissão de Representantes fiscalizar minuciosamente os negócios feitos pelo incorporador. Se os recursos obtidos com a negociação de unidades forem aplicados só no empreendimento, dificilmente os compradores serão lesados. Para os credores, a medida também é muito útil, pois os recursos obtidos com a venda de unidades serão destinados a pagar os trabalhadores da obra, os créditos fiscais e previdenciários e os fornecedores de material (MEZZARI, 2010, p. 139).

\section{A SEGURANÇA DO COMPRADOR E O PATRIMÔNIO DE AFETAÇÃO}

A utilização do Patrimônio de Afetação na incorporação atrai, como afirmado acima, certa segurança ao adquirente, mas os benefícios agregados pela Lei n. 4.591/64 também vinculam certo grau de incerteza, pois caso contrário, a sua própria aplicação seria obrigatória (SILVA, 2009, p. 254). 
Não se pode falar, assim, em um ambiente jurídico plenamente norteado pela segurança. A jurisprudência ${ }^{6}$, por exemplo, em razão de falência do incorporador que impossibilite a conclusão da edificação, trata os gastos efetuados pelo adquirente da unidade imobiliária como créditos quirografários, ou seja, de difícil recuperação em função de outras classes de créditos mais privilegiados e precedentes no recebimento.

A instituição do Patrimônio de Afetação agrega também dificuldades de gestão financeira ao incorporador, pois exige a separação entre a escrituração contábil do empreendimento e a do restante da incorporadora, principalmente quando houver a opção pelo Regime Especial de Tributação, com o qual é necessário que o empreendimento seja inscrito sob um novo número de CNPJ, distinto daquele do incorporador (REZENDE JUNIOR, 2013).

Essa exigência contábil aumenta a possibilidade de fraudes, pois como a lei permite a afetação a qualquer tempo, a separação contábil financeira se encontra prejudicada no tocante a operacionalidade, devido à dificuldade de separação de receitas e despesas, assim como das garantias e contratos firmados para as diferentes personalidades jurídicas.

Outro ponto controverso no Patrimônio de Afetação é a chamada "Comissão de Representantes". Ela é responsável pela fiscalização da incorporação, tendo acesso às instalações, bem como aos demonstrativos contábeis trimestralmente. Porém, tal comissão deve estar designada desde a afetação, e dessa forma, vinculada ao incorporador, somente podendo ser alterada com eleição em assembleia geral dos adquirentes das unidades imobiliárias (art. 50 da Lei n. 4.591/64).

Em caso de falência do incorporador, a "Comissão de Representantes" é competente para convocar assembleia geral e decidir pela manutenção da mesma "Comissão de Representantes" ou pela eleição de uma nova. Feito isso, caberá à Comissão deliberar sobre a liquidação ou continuação da obra. Caso se opte pela liquidação, caberá à Comissão alienar o patrimônio afetado, em nome dos condôminos (ROCHA, 2005). O patrimônio afetado será responsabilizado para o cumprimento das obrigações relativas a ele independentemente de continuar ou não a obra. Contudo, se a opção for a liquidação, ao final os adquirentes não serão mais devedores de nada; ao contrário, se sua opção for a continuidade7, serão responsabilizados integralmente por todos os tipos de dívidas provenientes da incorporação (SILVA, 2009, p. 254) . $^{8}$

\footnotetext{
${ }^{6}$ Vide REsp 1.185.336-RS, Rel. Luis Felipe Salomão, julgado em 2/9/2014.

${ }^{7}$ Há na Jurisprudência interessante tratamento, no caso de continuidade, admitindo, mesmo em face da Lei no 4.591/64 a exclusão do patrimônio da incorporadora falida e sua transferência aos adquirentes de unidades, viabilizando a continuidade das obras e assegurando a funcionalidade do contrato de
} 
incorporação. A ementa é a seguinte: PROCESSUAL CIVIL E IMOBILIÁRIO. INCORPORAÇÃO. FALÊNCIA ENCOL. TÉRMINO DO EMPREENDIMENTO. COMISSÃO FORMADA POR ADQUIRENTES DE UNIDADES. CONTRATAÇÃO DE NOVA INCORPORADORA. POSSIBILIDADE. SUB-ROGAÇÃO DA NOVA INCORPORADORA NOS DIREITOS E OBRIGAÇÕES DA ENCOL. INEXISTÊNCIA. SISTEMÁTICA ANTERIOR ÁS ALTERAÇÕES IMPOSTAS À LEI № 4.591/64 PELA LEI № 10.931/04. 1. Na hipótese dos autos, diante do inadimplemento da Encol, parte dos adquirentes de unidades do empreendimento se mobilizou e criou uma comissão objetivando dar continuidade às obras. Para tanto, essa comissão interviu nos próprios autos da falência, tendo obtido provimento jurisdicional autorizando que as "unidades estoque" (aquelas não comercializadas pela Encol) e as "unidades dos não aderentes" (daqueles que não quiseram aderir à comissão) fossem excluídas de qualquer vinculação com a massa falida, propiciando a retomada e conclusão da edificação, independentemente de qualquer compensação financeira. O juízo falimentar também autorizou, após a realização de assembleia geral, a substituição da Encol no registro imobiliário, o que levou a comissão a celebrar com a incorporadora recorrente um contrato de promessa de permuta, para que esta concluísse $o$ empreendimento, recebendo, em contrapartida, as unidades estoque e as unidades dos não aderentes. Há, pois, duas relações jurídicas absolutamente distintas: a primeira entre a Encol e os adquirentes originários de unidades do empreendimento; e a segunda entre a comissão de representantes desse empreendimento e a recorrente. Sendo assim, inexiste relação jurídica triangular que englobe a massa falida da Encol, os recorridos e a recorrente, a partir da qual esta teria se sub-rogado nos direitos e obrigações da Encol, o que justificaria a sua inclusão no polo passivo da execução movida pelos recorridos em desfavor da Encol. 2. Embora o art. 43, III, da Lei no 4.591/64 não admita expressamente excluir do patrimônio da incorporadora falida e transferir para comissão formada por adquirentes de unidades a propriedade do empreendimento, de maneira a viabilizar a continuidade da obra, esse caminho constitui a melhor maneira de assegurar a funcionalidade econômica e preservar a função social do contrato de incorporação, do ponto de vista da coletividade dos contratantes e não dos interesses meramente individuais de seus integrantes. 3. Apesar de o legislador não excluir o direito de qualquer adquirente pedir individualmente a rescisão do contrato e o pagamento de indenização frente ao inadimplemento do incorporador, o espírito da Lei no 4.591/64 se volta claramente para o interesse coletivo da incorporação, tanto que seus arts. 43 , III e VI, e 49, autorizam, em caso de mora ou falência do incorporador, que a administração do empreendimento seja assumida por comissão formada por adquirentes das unidades, cujas decisões, tomadas em assembleia, serão soberanas e vincularão a minoria. 4. Recurso especial provido. (STJ, Relator: Ministra NANCY ANDRIGHI, Data de Julgamento: 07/04/2011, T3 - TERCEIRA TURMA)

${ }^{8}$ Embora não seja o objeto direto do presente estudo registra-se que outras várias questões podem afetar a segurança na aquisição imobiliária via incorporação. É o caso da falência do incorporador, originando despesas aos adquirentes para a conclusão do prédio. Tais despesas ingressam como créditos comuns à massa falida. Esse é o entendimento em decisão do Superior Tribunal de Justiça, em 2014, com a seguinte ementa: "DIREITO EMPRESARIAL. FALÊNCIA DE INCORPORADORA IMOBILIÁRIA E CLASSIFICAÇÃO DOS CRÉDITOS ORIUNDOS DE DESPESAS EFETUADAS POR ADQUIRENTE DE IMÓVEL PARA A CONCLUSÃO DE PRÉDIO RESIDENCIAL.

Quando o adquirente de unidade imobiliária - em razão da impossibilidade de conclusão da edificação por parte da incorporadora responsável, ante a decretação de sua falência - tenha assumido despesas necessárias à conclusão do prédio residencial, os gastos desembolsados pelo adquirente devem ser inscritos no processo de falência da referida incorporadora como créditos quirografários. No processo falimentar, especialmente no tocante aos créditos habilitados, o princípio norteador é o da par conditio creditorum, na esteira do qual os credores do falido devem ser tratados em igualdade de condições, salvo se a lei expressamente dispuser de forma contrária, como ocorre com os créditos com preferências e privilégios eleitos pelo legislador como dignos de prioridade no pagamento. Neste contexto, o art. 43, III, da Lei 4.591/1964 (Lei de Incorporações Imobiliárias) preconiza que, no caso de decretação da quebra do incorporador e ante a impossibilidade de término da construção do edifício pela maioria dos adquirentes, estes se tornam credores privilegiados em relação aos valores já pagos ao incorporador pela compra do imóvel. Na hipótese em foco, o valor ora pleiteado é oriundo de mero ressarcimento dos custos das obras de finalização do empreendimento imobiliário. Assim, o crédito em análise não se encontra inserto em 
Outra alteração proveniente da lei 10.931/04 gerou uma pequena possibilidade do patrimônio afetado ser alvo de garantia real, porém tal possibilidade minimizada para operações de crédito que revertam produto integralmente a incorporação. Contudo, essa operação de crédito não necessita de aprovação contratual, pois já está disposta na lei (§3ㅇ do art. 31-A da Lei n. 4.591/64). Atualmente, o posicionamento do STJ é contrário ao disposto no §3ㅇ do art. 31-A da lei 4.591/64, utilizando para isto que a hipoteca, nestes casos, só seria oponível ao incorporador, e não ao adquirente, conforme REsp n 187.940-SP (BRASIL, 1999). Porém, esse argumento toma força quando fundamentado no Art. 39, V, do CDC, o qual dispõe que é nula toda cláusula que verse sobre vantagem manifestamente excessiva. Nesse sentido, alguns Tribunais têm decidido pela impossibilidade do gravame da incorporação completa após serem realizados contratos de compra e venda, pois dessa forma os direitos do consumidor adquirente estariam violados (TJDF. APC 19990110142308. 3a T.Cív. Rel. Des. Vasquez Cruxên. DJU 21.05.2003).

\section{CONSIDERAÇÕES FINAIS}

A partir das relações negociais imobiliárias, após o Caso ENCOL, é possível a verificação do retorno à aquisição de imóveis incorporados ainda na planta, ou seja, em fase de construção.

Com a exposição anterior, percebe-se que o instituto do Patrimônio de Afetação proporcionou incremento da segurança, para o promitente comprador, na aquisição de um imóvel proveniente de incorporação, constatado da normalidade do mercado imobiliário.

Esses novos direitos relacionados pela alteração de Lei no 10.931/04 relativizaram o direito real de hipoteca nas relações contratuais entre incorporador e agente financeiro. Apesar da hipoteca apresentar como característica o efeito erga omnes, o entendimento jurisprudencial aponta outra realidade, em que este direito só pode ser exercido contra o incorporador e não contra o adquirente de uma das unidades autônomas.

nenhuma das hipóteses previstas no art. 102, §§ 20 e 3ㅇ, do Decreto-Lei 7.661/1945 - que previa a classificação de créditos como privilegiados e especiais -, sendo certo, portanto, que a atribuição de privilégio previsto no art. 43, III, da Lei das Incorporações Imobiliárias refere-se, tão somente, aos créditos decorrentes das importâncias pagas ao incorporador pela aquisição das unidades autônomas, e não por despesas com construção do prédio residencial. REsp 1.185.336-RS, Rel. Luis Felipe Salomão, julgado em 2/9/2014."

Revista de Direito da Cidade, vol. 08, no 1. ISSN 2317-7721 pp.93-111 107 
Também nesta linha, percebe-se o incremento na segurança ao promitente comprador em casos que o patrimônio da incorporação é afetado, pois mesmo em casos de execuções contra o incorporador ou até de falência, são garantidos as instalações e insumos (presentes no canteiro de obras) para a continuidade da em casos, os quais a Comissão de Representantes assim decida.

As alterações legislativas trouxeram uma melhoria na segurança ao comprador, porém estas opções não são absolutas.

A dificuldade de contabilização decorrente da afetação patrimonial é um fato que pode proporcionar a ocorrência de fraudes, ou mesmo erros de lançamento. Com estes elementos incertos, a tomada de decisão pelo promitente comprador também pode incorrer em riscos.

Estas dificuldades de operacionalização podem ser percebidas até mesmo pela faculdade atribuída ao incorporador de afetar ou não o empreendimento como procedimento de garantia obrigatória do mesmo.

Há na Jurisprudência interessante tratamento, no caso de continuidade, admitindo, mesmo em face da Lei no 4.591/64, a exclusão do patrimônio da incorporadora falida e sua transferência aos adquirentes de unidades, viabilizando a continuidade das obras e assegurando a funcionalidade do contrato de incorporação. Isso reforça o objetivo teleológico da jurisprudência em preservar, o máximo possível, as possibilidades aos adquirentes.

Contudo, apesar destas dificuldades a alteração legislativa assim como os hábitos dos promitentes compradores favoreceram a um certo incremento de cautela antes de realizarem os negócios jurídicos com o incorporador.

\section{REFERÊNCIAS BIBLIOGRÁFICAS}

BRASIL. Superior Tribunal de Justiça. Sistema Financeiro Da Habitação. Casa própria. Execução. Hipoteca em favor do financiador da construtora. Terceiro promissário comprador. Embargos de terceiro. - Procedem os embargos de terceiros opostos pelos promissários compradores de unidade residencial de edifício financiado, contra a penhora efetivada no processo de execução hipotecária promovida pela instituição de crédito imobiliário que financiou a construtora. - 0 direito de crédito de quem financiou a construção das unidades destinadas à venda pode ser exercido amplamente contra a devedora, mas contra os terceiros adquirentes fica limitado a receber deles o pagamento das suas prestações, pois os adquirentes da casa própria não assumem a responsabilidade de pagar duas dívidas, a própria, pelo valor real do imóvel, e a da construtora do prédio. Recurso conhecido e provido. REsp. 187.940-SP, 4a Turma, Rel. Min. Ruy Rosado de Aguiar, julgado em 18-2-1999, DJ de 21-6-1999.

Superior Tribunal de Justiça. DIREITO EMPRESARIAL. FALÊNCIA DE INCORPORADORA IMOBILIÁRIA E CLASSIFICAÇÃO DOS CRÉDITOS ORIUNDOS DE DESPESAS EFETUADAS POR ADQUIRENTE DE IMÓVEL PARA A CONCLUSÃO DE PRÉDIO RESIDENCIAL. Quando o adquirente de

Revista de Direito da Cidade, vol. 08, no 1. ISSN 2317-7721 pp.93-111 108 
unidade imobiliária - em razão da impossibilidade de conclusão da edificação por parte da incorporadora responsável, ante a decretação de sua falência - tenha assumido despesas necessárias à conclusão do prédio residencial, os gastos desembolsados pelo adquirente devem ser inscritos no processo de falência da referida incorporadora como créditos quirografários. No processo falimentar, especialmente no tocante aos créditos habilitados, o princípio norteador é o da par conditio creditorum, na esteira do qual os credores do falido devem ser tratados em igualdade de condições, salvo se a lei expressamente dispuser de forma contrária, como ocorre com os créditos com preferências e privilégios eleitos pelo legislador como dignos de prioridade no pagamento. Neste contexto, o art. 43, III, da Lei 4.591/1964 (Lei de Incorporações Imobiliárias) preconiza que, no caso de decretação da quebra do incorporador e ante a impossibilidade de término da construção do edifício pela maioria dos adquirentes, estes se tornam credores privilegiados em relação aos valores já pagos ao incorporador pela compra do imóvel. Na hipótese em foco, o valor ora pleiteado é oriundo de mero ressarcimento dos custos das obras de finalização do empreendimento imobiliário. Assim, o crédito em análise não se encontra inserto em nenhuma das hipóteses previstas no art. 102, §§ 2으 e 3으, do Decreto-Lei 7.661/1945 - que previa a classificação de créditos como privilegiados e especiais -, sendo certo, portanto, que a atribuição de privilégio previsto no art. 43, III, da Lei das Incorporações Imobiliárias refere-se, tão somente, aos créditos decorrentes das importâncias pagas ao incorporador pela aquisição das unidades autônomas, e não por despesas com construção do prédio residencial. REsp 1.185.336-RS, Rel. Min. Luis Felipe Salomão, julgado em 2/9/2014.

Superior Tribunal de Justiça. PROCESSUAL CIVIL E IMOBILIÁRIO. INCORPORAÇÃO. FALÊNCIA ENCOL. TÉRMINO DO EMPREENDIMENTO. COMISSÃO FORMADA POR ADQUIRENTES DE UNIDADES. CONTRATAÇÃO DE NOVA INCORPORADORA. POSSIBILIDADE. SUB-ROGAÇÃO DA NOVA INCORPORADORA NOS DIREITOS E OBRIGAÇÕES DA ENCOL. INEXISTÊNCIA. SISTEMÁTICA ANTERIOR ÁS ALTERAÇÕES IMPOSTAS À LEI № 4.591/64 PELA LEI № 10.931/04. 1. Na hipótese dos autos, diante do inadimplemento da Encol, parte dos adquirentes de unidades do empreendimento se mobilizou e criou uma comissão objetivando dar continuidade às obras. Para tanto, essa comissão interviu nos próprios autos da falência, tendo obtido provimento jurisdicional autorizando que as "unidades estoque" (aquelas não comercializadas pela Encol) e as "unidades dos não aderentes" (daqueles que não quiseram aderir à comissão) fossem excluídas de qualquer vinculação com a massa falida, propiciando a retomada e conclusão da edificação, independente de qualquer compensação financeira. O juízo falimentar também autorizou, após a realização de assembleia geral, a substituição da Encol no registro imobiliário, o que levou a comissão a celebrar com a incorporadora recorrente um contrato de promessa de permuta, para que esta concluísse o empreendimento, recebendo, em contrapartida, as unidades estoque e as unidades dos não aderentes. Há, pois, duas relações jurídicas absolutamente distintas: a primeira entre a Encol e os adquirentes originários de unidades do empreendimento; e a segunda entre a comissão de representantes desse empreendimento e a recorrente. Sendo assim, inexiste relação jurídica triangular que englobe a massa falida da Encol, os recorridos e a recorrente, a partir da qual esta teria se sub-rogado nos direitos e obrigações da Encol, o que justificaria a sua inclusão no polo passivo da execução movida pelos recorridos em desfavor da Encol. 2. Embora o art. 43, III, da Lei no 4.591/64 não admita expressamente excluir do patrimônio da incorporadora falida e transferir para comissão formada por adquirentes de unidades a propriedade do empreendimento, de maneira a viabilizar a continuidade da obra, esse caminho constitui a melhor maneira de assegurar a funcionalidade econômica e preservar a função social do contrato de incorporação, do ponto de vista da coletividade dos contratantes e não dos interesses meramente individuais de seus integrantes. 3. Apesar de o legislador não excluir o direito de qualquer adquirente pedir individualmente a rescisão do contrato e o pagamento de indenização frente ao inadimplemento 
do incorporador, o espírito da Lei no 4.591/64 se volta claramente para o interesse coletivo da incorporação, tanto que seus arts. 43, III e VI, e 49, autorizam, em caso de mora ou falência do incorporador, que a administração do empreendimento seja assumida por comissão formada por adquirentes das unidades, cujas decisões, tomadas em assembleia, serão soberanas e vincularão a minoria. 4. Recurso especial provido. (STJ, Relator: Ministra NANCY ANDRIGHI, Data de Julgamento: 07/04/2011, T3 - TERCEIRA TURMA)

LEI № 4.591, de 16 de dezembro de 1964. Dispõe sobre o condomínio em edificações e as incorporações imobiliárias. Brasília. Publicado no DOU de 21.12.1964 e retificado no DOU de 1.2.1965.

LEI N 6.496, de 7 de dezembro de 1977. Institui a " Anotação de Responsabilidade Técnica " na prestação de serviços de engenharia, de arquitetura e agronomia; autoriza a criação, pelo Conselho Federal de Engenharia, Arquitetura e Agronomia - CONFEA, de uma Mútua de Assistência Profissional; e dá outras providências. Brasília. Publicado no D.O.U. de 9.12.1977

LEI № 8.078, de 11 de setembro de 1990. Dispõe sobre a proteção do consumidor e dá outras providências. Brasília. Publicado no D.O.U. de 12.9.1990 - (Edição extra) e retificado no DOU de 10.1.2007.

LEI № 10.406, de 10 de janeiro de 2002. Institui o Código Civil. Brasília. Publicado no DOU de 11.1.2002.

CHALHUB, Melhim Namem. Curso de direito civil: direitos reais. Rio de Janeiro: Forense, 2003.

DF. Tribunal de Justiça do Distrito Federal e dos Territórios. CIVIL. COMPRA E VENDA. INCORPORAÇÃO. LEI 4.591/64. MASSA FALIDA DA ENCOL S/A. HIPOTECA. VIOLAÇÃO AOS DIREITOS DO CONSUMIDOR. ART. 51 DO CDC. ANUÊNCIA PARA TAL GRAVAME. APÓS A AVERBAÇÃO DA INCORPORAÇÃO E REALIZADOS OS CONTRATOS DE PROMESSA DE COMPRA E VENDA COM TERCEIROS, É IMPOSSÍVEL ONERAR O IMÓVEL COMO UM TODO, PORQUE ESTAR-SE-IA VIOLANDO O DIREITO DO CONSUMIDOR ADQUIRENTE, QUE PAGOU OU VEM PAGANDO A CONTENTO SUAS PRESTAÇÕES. A PENHORA OU HIPOTECA SÓ PODE SER PERMITIDA COM A EXPRESSA ANUÊNCIA DOS PROMITENTES-COMPRADORES, NÃO BASTANDO, PARA TAL FIM, CLÁUSULAS GENÉRICAS QUE PREVÊEM A POSSIBILIDADE DE DAR EM GARANTIA, PARA FINANCIAMENTO, OS TERRENOS E AS UNIDADES CONSTRUÍDAS. APC 19990110142308. 3a T.Cív. Rel. Des. Vasquez Cruxên. Julgado em 17/02/2003. DJU 21.05.2003.

FARIAS, Cristiano Chaves de; ROSENVALD, Nelson. Curso de Direito Civil - Reais. 11. ed.rev. ampl. e atual. São Paulo: Atlas, 2015.

FERNANDES, Fátima; ARBEX, Mauro. Efeito Encol paralisa venda de imóveis. Folha de São Paulo, São Paulo, 26 ago 1997. Folha Mercado. Disponível em: <http://www1.folha.uol.com.br/fsp/1997/8/26/dinheiro/1.html>, acesso em 25/10/2013.

GIL, Antonio Hernández. La posesión como institución jurídica y social. Madrid: Espasa- Calpe, 1987.

GONÇALVES, Carlos Roberto Direito civil brasileiro [Ebook], volume 5: direito das coisas / Carlos Roberto Gonçalves. - 7. ed. - São Paulo: Saraiva, 2012.

MEZZARI, Mario Pazutti. Condomínio e incorporação no Registro de Imóveis. 3 ed. Porto Alegre: Norton Editor, 2010. 
RELATÓRIO final da massa falida da Encol é entregue à Justiça, em Goiás. 2013, disponível em: <http://g1.globo.com/goias/noticia/2013/05/relatorio-final-da-massa-falida-da-encol-e-entreguejustica-em-goias.html>, acesso em 18/10/2013.

REZENDE JUNIOR, Nelson Couto de. O Patrimônio de Afetação - Aspectos Civis Práticos. 2013, disponível em: <http://www.agkn.com.br/atualidades/87-o-patrimonio-de-afetacao-aspectos-civispraticos>, acesso em 15/10/2013.

ROCHA, Mauro Antônio. O regime da afetação patrimonial na incorporação imobiliária. 2005, disponível em: <http://www.irib.org.br/html/biblioteca/biblioteca-detalhe.php?obr=61\#_edn2>, acesso em 15/10/2013.

SILVA, Bruno Mattos e. Compra de imóveis: aspectos jurídicos, cautelas devidas e análise de riscos. 7 ed. São Paulo: Atlas, 2009.

SILVA, José Marcelo Tossi. Incorporação imobiliária. São Paulo: Atlas, 2010.

VENOSA, Sílvio de Salvo. Direito Civil - Teoria Geral das Obrigações e Teoria Geral dos Contratos. Volume 2. 13 $3^{\text {a }}$ edição. São Paulo: Atlas, 2013.

Trabalho enviado em 20 de agosto de 2015.

Aceito em 20 de janeiro de 2016. 